\title{
Adversaries on Covid-19 Set Forth an Argument Onward To Educational Endeavor: Resulting To Develop a Modular Concept in the Learning Process
}

\author{
Edilmar P. Masuhay \\ Bachelor of Agricultural Technology (BAT) Department \\ Surigao State College of Technology (SSCT) - Mainit Campus \\ Magpayang, Mainit, Surigao del Norte, Philippines \\ E-mail: yahusamedilmar@gmail.com
}

\begin{abstract}
The study observed on how COVID-I9 disturbed the universe, its detrimental factors to detriment the constituents in particular to educational endeavor, the outcomes to teachers and to the learners. Yet, on the contrary this is also an opportune to extend teaching stratification whom a concluding scenarios that sometimes attending classes in the classrooms were insignificant not unless for formative assessment, $2 \mathrm{I}^{\text {st }}$ pedagogues more probably applicable whereby lectures can be done thru social media (blogs, group chats, emails). The study conveyed also that research-output-based teaching methods are more desirable as if students would be taught on how to be a writer and a researcher. However, this COVID-I9 reciprocally demean traditional maneuvers hence attendance literally are not necessary, this is a resolution of vanishing the old methods of teaching but on the other hand modular concept has led to resolve the issue. This COVID-I9 definitely an uprising of a new beginning onward to educational teaching stratification but subsequently this is also threatening students of which their only avenue to attain the learning process is going to internet café where they are exposed, and prohibited for safety precautions. This disease skeptically made excuses for those who were non-focus, malingered individual either to their studies or duty, this even defying one's authority for a reason of security, a banishment of those known with infected disease, and economically the Local Government Unit (LGU) were suppressive.
\end{abstract}

Keywords: COVID-I9, CHED Covid-19 Advisories, Covid-I9 Preventive Measures, Modular Learning-Process, Social Media.

\section{Introduction}

In the midst of crisis one's judgments sometime were greedily twisted, their principles, desires, commitment are uncertain. Everyone has his/her reasons, opinions, and arguments to elucidate for his own satisfaction or for the common good, their indifferences showcase, other may incline or decline to believe and pathetically breaking one's heart turning this simple misunderstanding to a debate but still at the end everyone are reunited, contributed their patriotic efforts, time, assistance for patriotism and nationalism.

\section{Statement of the Problem}

Duddu (2020) on his report emphasized that the Philippines is one of among the high-risk countries from the Wuhan coronavirus outbreak, a disease originated from China, of which there were over 80 percent of cases and deaths. This scenario has led the Philippines government announced lock-down of Metro Manila and is mulling over more localized lock-downs.

Although, Fumento (2020) on his statement expound that Worldwide, there have been about 3,400 coronavirus deaths, out of about 100,000 identified cases. Flu, by comparison, grimly reaps about 29I,000 to 646,000 annually, but its cases peaked and began declining more than a month ago, according to data presented by the Canadian epidemiologist who spearheaded the World Health Organization's (WHO) coronavirus mission to China. This even forecast that out of 200 new cases reported daily, down from a peak of 4,000 this pattern subsequently same of some extent countries in what's called Farr's Law, first formulated in 1840 and ignored in every epidemic hysteria since, the law states that epidemics tend to rise and fall in a roughly symmetrical pattern or bell-shaped curve. AIDS, SARS, Ebola - they all followed that pattern. So does seasonal flu each year. Clearly, flu is vastly more contagious than the new coronavirus, as the WHO has noted. Apparently, from the Journal of the American Medical Association it is reported that Chinese government analyzed that Corvid-I9 death ratio, showcase that for age 40's accumulated 0.2 percent death, I 4.8 percent above 80 's, and found zero deaths worldwide among children with ages 9 and below. As it is also enlightened that Philippines climatic nature is more impervious compared to other affected countries, 
because it hot and humid, so far there were no confirmed cases of internal transmission Yet, there are cases that patients with travel history abroad were confirmed affected with the said disease.

However, the Department of Health (DOH) has accumulated reports that there were five (5) confirmed cases of the Coronavirus Disease 2019 (COVID-19) in the Philippines (Department of Health website, n.d.):

First, a 48-year-old male Filipino with travel history to Japan, who was confined on February 25 and experienced chills and fever beginning March 3, sought medical consultation for testing and with positive result on COVID-I9 on March 5, currently stable and admitted at the Research Institute for Tropical Medicine;

Second, a 62-year-old male Filipino with known hypertension and diabetes mellitus, who experienced cough with phlegm last February 25, this patient sought medical consultation at a hospital in Metro Manila last March I and was admitted with severe pneumonia. Specimen collected on March 4 tested positive for COVID-19 on March 5, and has no known history of travel outside of the country, contact tracing is being done for the two cases and samples have already been collected from close contacts;

Third, a 38-year-old Taiwanese male who visited the Philippines from February 28 to March 3. He developed abdominal discomfort and diarrhea on March 2, and experienced sore throat, fever, and malaise on March 3. The patient consulted at an outpatient clinic in Taiwan on March 4, and was confirmed positive for COVID-I9 on March 5. The onset of symptoms on March 2 points to possible infection before the patient traveled to the Philippines;

Fourth, a 44-year-old Japanese male who visited the Philippines from February 2I to 28. Prior to visiting the Philippines, he traveled to Cambodia, Vietnam, Thailand, and Japan. He stayed at three different hotels during his visit to Metro Manila. The 44-year-old flew back to Thailand last February 28 and experienced cough, shortness of breath, and fever which began on February 29. The patient consulted at a clinic in Cambodia on March 3 and was referred to a hospital but no tests were done. He flew back to Japan last March 4 and was tested positive for COVID-I9. The patient was admitted and is still in isolation at Aichi Prefecture Hospital. The extensive travel history of the patient suggests possible contraction of the disease in another country; and

Fifth, a female living in Sydney, Australia. The patient attended a wedding in Manila on February I3 and visited Pangilinan. The patient left the country for Sydney on March 2, and was confirmed with COVID-I9 by the New South Wales Government on March 3. As for this case, DOH is still verifying information with the International Health Regulation National Focal Point Australia.

This cases of Covid-19 has ruined the standard for Philippines educational pedagogues and thereby administrators, educators, teachers, researchers, concerned parties wishes to stratifies the learning process. Thus, the author came up this study to investigate how this Covid-19 impacted the educational endeavor, and its intimacy to and for the constituents.

\section{Significances of the Study}

This study tried to fixed arguments that help to clarify issues on Covid-19 to resilient crisis against the educational endeavor as means to neutralize the panic situation of every teacher, parent, administrator, and student in particular to the Surigao State College of Technology (SSCT) - Mainit Campus, Magpayang, Mainit, Surigao del Norte, Philippines.

\section{Research Objectives}

Resemblance to crisis resiliency, this study explored, investigated, collated data relative on COVD-I9 and its effect to educational learning process. This particularly showed evident scenarios on how the diseases ruined the economy, the political will of the country, and the educators' teaching stratification.

\section{Research Questions}

- What are the arguments of educators about Covid-19 in the learning process?

- How Surigao State College of Technology managed this crisis on Covid-I9 in order to sustain the learning process?

\section{Review of the Literature}

This part of the study explores, collected, documented previous studies related to adversaries on Covid-19 and its specific impact towards the education learning process. It is also displays different point of views amongst the government officials' concepts, policies and principles on issues therein. Moreover, (Duddu, 2020) has contemplated this scenario thru his report which can be found as explained literally on the following paragraphs' below.

\section{When did coronavirus reach the Philippines?}

The first case of novel coronavirus (2019-nCoV, now COVID-19) in the Philippines was confirmed on 30 January 2020, in a 38-year old woman who arrived from Wuhan. Two days later, the Philippines recorded the first death outside China on OI February 2020. The Philippines government declared a health emergency on 09 March, following a spike in new confirmed 
cases and local transmission. The move will release funds to local governments and healthcare officials to handle any further surge in cases. The COVID-I9 Code Alert system was revised upwards to Red Sublevel 2 on I2 March. Coronavirus: Philippines COVID-I9 cases and deaths. As of 16 March, the total COVID-I9 cases in the Philippines stand at I42. One of the coronavirus-confirmed on 06 March was confirmed to be a human-to-human transmission putting the nation on a high alert. The man attended prayer in late February, which increases the concerns of possible transmission to other devotees who attended the same. The 44-year old Chinese national, who died, was the relative of the first patient diagnosed with COVID-I9. The patient developed severe pneumonia.

\section{Coronavirus-affected Filipinos on Diamond Princess Cruise ship}

Seven passengers onboard the Diamond Princess Cruise ship and more than half of the crew are from the Philippines, among who 80 have been confirmed to have contracted the virus. The Philippines government repatriated 445 of its citizens onboard the ship including ten recovered cases on 25 February. The evacuees have been placed under a two-week quarantine at New Clark City in Capas. A total of 70 confirmed cases were not allowed to board the evacuation flight.

\section{How risky is coronavirus to the Philippines?}

Due to its proximity to China, the Philippines is at a far greater risk of witnessing increased cases of the novel coronavirus infection compared to other countries. The Philippines is also home to hundreds of workers from China working in the Philippine Offshore Gambling Operation (firms offering online gambling services). More than 230,000 migrant Filippinos often referred to as Overseas Filipino Workers (OFW) are also working in China particularly Hong Kong and Macau as household workers. A temporary ban was imposed on the workers from travelling to China or its special administrative regions after the coronavirus outbreak on 2 February. The ban was lifted on I8th February allowing OFWs to return to Hong Kong and Macau. Manila is among the top 30 global cities receiving airline passengers from 18 high-risk cities in China, according to WorldPop which ranked Philippines $\mathrm{I}^{\text {th }}$ among the 30 high-risk countries.

Chinese nationals account for the majority of the tourist population visiting the country as trade and cultural relations have increased between the two countries in the recent past.

\section{Lock-down of affected areas}

The Philippines government started announcing local lock-downs (home quarantine) following the increase in global coronavirus cases. The entire Luzon Island is locked-down affecting more than 50 million people. Metro Manila lock-down was announced on 12 March and will continue until I4 April, while similar quarantine measures are expected in Bohol and Cainta provinces. Davao City has imposed travel restrictions. Quarantining (lock-down) will be imposed in the Philippines barangays, municipalities/cities and provinces if at least two COVID-I9 coronavirus cases are recorded in two different households in the respective locations. Quezon City declared a state of calamity due to coronavirus on 13 March, which means that the city can access Quick Response Fund to combat the outbreak.

What Metro Manila lock-down means for residents and visitors. During the lock-down, domestic transportation of all modes including land, air, and sea are suspended.

\section{Preventive measures by the Philippines government}

The Philippines government is taking several steps to control the spread of the virus, including travel restrictions, closure of schools and colleges, as well as training schools of the Philippines National Police.

Educational institutes in the country are announced to be closed from 09 March to I5 March, whereas in Metro Manila the classes will be suspended until I2 April. Stringent social distancing measures will be in place in the National Capital Region (NCR) for 30 days from I5 March.

The government announced earlier on 2 February 2020 that all persons except Filipino citizens and permanent resident visa holders were temporarily barred from entering the country. A temporary ban on Filipinos from travelling to China or its special administrative region was also imposed. Mandatory I4-day quarantine for Filipinos returning to from China or its special administrative region was announced. Further, visa upon arrival for Chinese nationals has been temporarily suspended.

\section{Travel ban to South Korea}

The Philippines government issued a temporary ban on 26 February on all citizens from travelling to South Korea, as the country reported a spike in the number of confirmed cases. Further, people from the affected regions of South Korea including Gyeongbuk, Daegu and Cheongdo have been banned from entering into the country. 


\section{Coronavirus in the Philippines: Measures at airports}

The Philippines Government announced travel restrictions to and from China, Hong Kong, and Macau to minimize the spread. It also banned the entry of passengers from the three countries.

India and Thailand.

Airlines cancelled flights from the Philippines to China resulting in stranding. Face masks shortage - importing from

The Philippines witnessed a surge in demand for face masks as fears over the coronavirus infection increased, despite assurance from the government that there is no need to wear face masks yet.

The government reiterated that healthcare workers and patients with symptoms of the disease should be given priority for masks.

The Philippines International Trading Corporation (PITC), meanwhile, identified two face mask suppliers from India and Thailand to meet the demand for face masks.

The suppliers are expected to take more than 30 days to supply the masks. The India-based supplier is expected to supply one million units, while the exact number of face masks that the Thailand-based supplier can supply is yet to be determined. The masks will be imported either by the DOH or the PITC.

\section{Coronavirus outbreak: Impact on the Philippines \\ Impact on the economy}

Philippines witnessed a slower economic growth in the first half of 2019, compared to 20I8. The country saw a sustained economic growth of $6.3 \%$ between 2010 and 2018, while the growth slowed down to 5.5\% in H2 2019. The World Bank estimates Philippines to witness full-year 2019 economic growth of $5.8 \%$. The ongoing coronavirus impact is expected to result in a subdued growth for the economy in 2020. China is Philippines' top trading partner accounting for I8.8\% of total trade, according to the Philippine Statistics Authority (PSA). In November 2019, 22.9\% of Philippines' exports were to China, the biggest importer for the country.

Philippines imports account for approximately 20\% of goods from China followed by Korea and Japan at I0\% each. The Central Bank of the Philippines (BSP) noted that the coronavirus outbreak could have a major impact on Philippine economy over the next few months. Ruben Carlo Asuncion, chief economist for Union Bank of the Philippines, noted that the coronavirus outbreak could cost the Philippine economy $\$ 600 \mathrm{~m}$ or $0.8 \%$ of economic growth if it lasts for six months, as quoted by CNN Philippines.

\section{Fiscal measures to contain the coronavirus impact}

The central bank also announced its decision to reduce interest rate on reverse repurchase (RRP) facility by 25 basis points to $3.75 \%$ on 06 February 2020. The interest rate on overnight lending and deposit facilities was also cut to $4.25 \%$ and $3.25 \%$, respectively. The projected gross domestic growth rate of $6.5 \%-7.5 \%$ for 2020 , however, has not been revised.

\section{Impact on tourism}

Tourism industry is a major contributor, accounting for $12.7 \%$ of the Philippine economy in 2018, according to data from the Philippines Statistics Authority. More than seven million foreign tourists visited the country during the first ten months of 2019. Chinese tourists account for majority of Philippines' tourist population. During the first ten months of 20I9, a total of I.49 million Chinese tourists visited the Philippines, according to the Department of Tourism (DOT). Philippine tourism officials expected to attract four million Chinese tourists by 2022, before the outbreak happened. The tourism industry, however, is expected to witness a major impact as the country closed its borders with China and other countries due to the coronavirus infection, Philippine Finance Secretary Carlos Dominguez noted. Dominguez added that the exact economic impact of the outbreak is too early to be estimated but remained optimistic that the country can sustain its economic growth.

\section{I Adversaries on Covid-I9}

In December 2019, an outbreak of severe acute respiratory syndrome coronavirus 2 (SARS-CoV-2) infection occurred in Wuhan, Hubei Province, China and spread across China and beyond. On February 12, 2020, WHO officially named the disease caused by the novel coronavirus as Coronavirus Disease 2019 (COVID-I9). Since most COVID-I9 infected patients were diagnosed with pneumonia and characteristic Computed Tomography (CT) imaging patterns, radiological examinations have become vital in early diagnosis and assessment of disease course. To date, CT findings have been recommended as major evidence for clinical diagnosis of COVID-19 in Hubei, China. This review focuses on the etiology, epidemiology, and clinical symptoms of COVID-I9, while highlighting the role of chest CT in prevention and disease control ( $\mathrm{Zu}$, et.al, 2020); (Chen, et.al, 2020); (Fang, et.al, 2020)

On the contrary a group public health professional scientists and medical professionals of China, in particular, have who have closely followed the emergence of 2019 novel coronavirus disease (COVID-I9) and are deeply concerned about its impact on global health and wellbeing, worked diligently and effectively to rapidly identify the pathogen behind this outbreak, 
put in place significant measures to reduce its impact, who continue to save lives and protect global health during the challenge of the COVID-I9 outbreak with their counterparts in the forefront, against this new viral threat. They also emphasized that COVD-19 threatened by rumors and misinformation around its origins, and they urged that everyone should stand together to strongly condemn conspiracy theories suggesting that COVID-I9 does not have a natural origin but based on analytical theories Scientists from multiple countries have published and analyzed genomes of the causative agent, severe acute respiratory syndrome coronavirus 2 (SARS-CoV-2) and they overwhelmingly conclude that this coronavirus originated in wildlife, as have so many other emerging pathogens. This is further supported by a letter from the presidents of the US National Academies of Science, Engineering, and Medicine and by the scientific communities they represent. Conspiracy theories do nothing but create fear, rumors, and prejudice that jeopardize our global collaboration in the fight against this virus (Calisher, et.al, 2020); (Heymann \& Shindo, 2020); (Bernheim, 2020); (Shi, 2020).

In summary, this short review of papers indicates that students would be interested in studying topics around extreme natural events when taught via pedagogies involving inquiry-based practices (critical, practical and action oriented). Both the natural and human processes need to be considered equally, with looting, community cooperation, and involvement being critical in the social education component of the human side of an extreme natural event. The COVID-19 issue is not a purely epidemiological phenomenon. It is also a social phenomenon and education for crises such as this should include teaching about the need for empathy. The example of the person who suffered a heart attack where none of the bystanders offered any help is testament to the need for more empathy. Attitudes and values show a distance-decay effect, which will impact teaching efforts. However, with an event like the COVID-I9 crossing borders in an increasingly mobile world, the efforts in education may be challenged in other ways. Misconceptions can be linked to misinformation at times of extreme natural events, and reveal suppressed xenophobic beliefs. Globalization is accelerating the need for both school and general public education around extreme natural events, and education needs to include aspects of social learning. We need to teach students and the general public that, in times of crisis, people's abilities are compromised, and we say and do things we would not normally say or do. We need to be aware of this and be equipped to perform under these times of uncertainty and pressure. Further study is needed to develop a new approach and to determine the effects of new pedagogical methods with respect to social learning around extreme natural events. International Research in Geographical and Environmental Education (IRGEE) looks forward to more research that will help us better understand the issues in curriculum and instruction for hazard and crisis education. It is a great challenge for geography and environmental education to develop and contribute to enhancing social media use awareness by taking into account the aforementioned aspects (Kidman \& Chang, 2020).

The disease has also been exported to other countries, including the Philippines, but the level of spread is still under control (as of 08 February 2020). To describe and predict the dynamics of the disease, several preliminary mathematical models are formulated by various international study groups. Here, the insights that can be drawn from these models are discussed, especially as inputs for designing strategies to control the epidemics. Proposed model-based strategies on how to prevent the spread of the disease in local setting, such as during large social gatherings, are also presented. The model shows that the exposure time is a significant factor in spreading the disease. With a basic reproduction number equal to 2, and I4-day infectious period, an infected person staying more than 9 hours in the event could infect other people. Assuming the exposure time is 18 hours, the model recommends that attendees of the social gathering should have a protection with more than 70 percent effectiveness (Rabajante, 2020).

\subsection{Impact of COVID-19 to Teachers-Students in the Learning Process}

This Covid-I9 has ruined the Surigao State College of Technology (SSCT) educational schemes, by de jure the Commission on Higher Education (CHED) proclaimed to suspend classes for safety purposes

The CHED has release an advisory ordering all the Presidents of Higher Education Institutions (HEIs) that the State Universities and Colleges (SUCs) must discuss measures to the undertaken with their respective Boards of Regents (BOT) and inform the CHED regional office of such activities (Signed by) Chairman J. PROSPERO E. DE VERA, DPA. This is in lieu to His Excellency President Rodrigo Roa Duterte Proclamation No. 922 series of 2020,

Consonant, the SUCs President of SSCT has progressively ordered that all faculty should prepared a module; created an skeletal team as work force; for humanitarian reasons allows Job orders and Guest lectures to continually in the service; nondesignated teachers were allowed to work at home and prepared logbook on their daily time records (DTR).

\section{Research Methodology}

This research is anthropological and sociological in nature. (Frank \& Langness, 198I); (Leach, 2020); (Sadati, Lankarani, Hossein \& Bagheri, n.d.); Peckham, R. (2020); (Harding \& Taylor, 2002). 


\section{I Research Types and Sampling Method}

This is a phenomenal research looking for an avenue to hold proper citation and guidance against the conflicting interest of everyone's desires, opinions, arguments and commitment onward to Covid-I9 implications, and resilience actions of government officials, educators and all parties concerns forward to education. Study is more on observation, dependent on previous related data and studies, this is plain descriptive and logical.

\subsection{Data Collection Procedures}

Gathering of data is simply done conveniently thru downloading of previous literatures from social media-reports (goggle websites), articles, decrees, memos, orders. Logical interpretations were rested under discussion subsection at the author's level of perspective if in case of doubts and critiques, this study profoundly restful.

\subsection{Research Instrument}

Observation has been employed on this study wherein the public has been observed keenly by the author on how the environment influenced to eradicate the norms or the system of public governance. In this study the researcher interacts with people in everyday life while collecting information, investigating the enormously rich, complex, conflictual, problematic, and diverse experiences, thoughts, feelings, and activities on COvid-I9. This method emerged with the professionalization of anthropology and sociology where it gradually was formalized and later spread to a full range of human studies fields. Its practice nevertheless remains artful, requiring creative decision making about problems and questions to be studied, appropriate settings and situations for gathering information, the performance of membership roles, establishing and sustaining trusting relationships, ethics, values, and politics, as well as record making, data analysis and interpretation, and reporting results (Jorgensen, 2015).

Structurally, there is no instrument used but the outcomes would reveals either to showcase the positive and negative results of the reigning verdict invoked by the administrator and the policy-makers.

\section{Findings and Discussions}

This country is under authoritarian policy though, democratic in governance. Everyone government role's over the constitutional legitimacy wherein no one is allowed to do his own action without following mandates from the written constitution. But this study does not tended to showcase about the political issue therein of the country rather this study focus only to answers questions on: first, What are the arguments of educators about Covid-19 in the learning process?; and second, How Surigao State College of Technology managed this crisis on Covid-I9 in order to sustain the learning process?

Below are the revelations, which serve to be the findings which serves to answers those questions enumerated above:

\section{Arguments of educators about Covid-I9 in the learning process CHED-COVID-I9 ADVISORY NO. 3}

In response to the directive of President Rodrigo Roa Duterte through Proclamation No. 922 series of 2020, the commission has release an advisory ordering all the Presidents of Higher Education Institutions (HEIs) that the State Universities and Colleges (SUCs) must discuss measures to the undertaken with their respective Boards of Regents (BOT) and inform the CHED regional office of such activities (Signed by) Chairman J. PROSPERO E. DE VERA, DPA. This advisory aspired the author to create his own desired module as an output (See Appendix A).

\section{Conclusion}

The Philippines is under authoritarian policy though, democratic in governance, governance roles over the constitutional legitimacy wherein no one is allowed to do his own action without following mandates from the written constitution. But this study does not tended to showcase about the political issue therein of the country rather this study focus only to answers questions on: first, What are the arguments of educators about Covid-I9 in the learning process?; and second, How Surigao State College of Technology managed this crisis on Covid-19 in order to sustain the learning process?

Based on findings raised questions ( $\mathrm{I}$ and 2 ) were absolutely satisfied, results has been displayed, and discussed yet SSCT has contemplated their desire by preparing module to attain the tended learning process but this possibly negated because the reality condemn any activities therein that threatened the safety of the students such that social media and any related events.

\section{References}

Bernheim, A., Mei, X., Huang, M., Yang, Y., Fayad, Z. A., Zhang, N., \& Li, S. (2020). Chest CT findings in coronavirus disease-I9 (COVID-I9): Relationship to duration of infection. Radiology, 200463.

Calisher, C., Carroll, D., Colwell, R., Corley, R. B., Daszak, P., Drosten, C.,\& Gorbalenya, A. (2020). Statement in support of the scientists, public health professionals, and medical professionals of China combatting COVID-I9. The Lancet. 
Ched urges schools to prepare for possible coronavirus 'community-level transmission.' (n.d.). Rappler. Retrieved March I8, 2020, from http://www.rappler.com/nation/2542I4-ched-urges-schools-prepare-possible-community-leveltransmission-coronavirus.

Chen, H., Guo, J., Wang, C., Luo, F., Yu, X., Zhang, W., \& Liao, J. (2020). Clinical characteristics and intrauterine vertical transmission potential of COVID-I9 infection in nine pregnant women: a retrospective review of medical records. The Lancet.

Doh confirms two more cases of COVID-I9 In Ph | Department of Health website. (n.d.). Retrieved March I7, 2020, from https://www.doh.gov.ph/doh-press-release/DOH-CONFIRMS-TWO\%20MORE-CASES-OF-COVID-I9-IN$\mathrm{PH}$.

Duddu, P. (2020). Coronavirus in Philippines: how the COVID-I9 affects Philippines. (n.d.). Retrieved March I7, 2020, from https://www.pharmaceutical-technology.com/features/coronavirus-affected-countries-philippines-measuresimpact-tourism-economy/.

Fang, Y., Zhang, H., Xie, J., Lin, M., Ying, L., Pang, P., \& Ji, W. (2020). Sensitivity of chest CT for COVID-I9: comparison to RT-PCR. Radiology, 200432.

Frank, G., \& Langness, R. (I98I). Lives: An anthropological approach to biography. Novato, Calif.: Chandler \& Sharp Publishers.

Fumento, M. (2020). Coronavirus going to hit its peak and fall sooner than you think. (n.d.). Retrieved March 17, 2020, from https://nypost.com/2020/03/08/coronavirus-going-to-hit-its-peak-and-start-falling-sooner-than-you-think/.

Gimeno, J. (2020). UNICEF Philippines statement on COVID-19. Retrieved March 17, 2020, from https://www.unicef.org/philippines/press-releases/unicef-philippines-statement-covid-I9.

Harding, G., \& Taylor, K. (2002). Social dimensions of pharmacy : (4) Health, illness and seeking health care. Pharmaceutical Journal, 269, 526-528.

Heymann, D. L., \& Shindo, N. (2020). COVID-I9: what is next for public health? The Lancet.

Jorgensen, D. L. (2015). Participant observation. Emerging trends in the social and behavioral sciences: An interdisciplinary, searchable, and linkable resource, I-I5.

Kidman, G., \& Chang, C. H. (2020). What does “crisis” education look like?.

Leach, M. (2020). Echoes of Ebola: social and political warnings for the COVID-I9 response in African settings. Echoes.

Malipot, M.H. (2020). DepEd: Use of social media for learning still 'discouraged' despite COVID-I9 threat » Manila Bulletin News. (n.d.). Retrieved March 17, 2020, from https://news.mb.com.ph/2020/03/13/deped-use-of-social-mediafor-learning-still-discouraged-despite-covid-I9-threat/.

News, A.-C. (n.d.). CHED tells affected schools to move graduation dates amid COVID-I9 scare. ABS-CBN News. Retrieved March 18, 2020, from https://news.abs-cbn.com/news/03/I5/20/ched-tells-affected-schools-to-movegraduation-dates-amid-covid-I9-scare.

Peckham, R. (2020). COVID-I9 and the anti-lessons of history. The Lancet.

Rabajante, J. F. (2020). Insights from early mathematical models of 20I9-nCoV acute respiratory disease (COVID-I9) dynamics. arXiv preprint arXiv:2002.05296.

Sadati, A. K., Lankarani, B., Hossein, M., \& Bagheri Lankarani, K. (n.d.). Risk Society, Global Vulnerability and Fragile Resilience; Sociological View on the Coronavirus Outbreak.

Shi, H., Han, X., Jiang, N., Cao, Y., Alwalid, O., Gu, J., \& Zheng, C. (2020). Radiological findings from 8 I patients with COVID-I9 pneumonia in Wuhan, China: a descriptive study. The Lancet Infectious Diseases.

Twitter, Twitter, \& Twitter. (n.d.). Graduation rites suspended in Bacolod City schools. Retrieved March 20, 2020, from https://www.pna.gov.ph/articles/I096457.

UP Diliman - University of the Philippines. (n.d.). Retrieved March 20, 2020, from https://www.up.edu.ph/index.php/tag/up-diliman/.

Zu, Z. Y., Jiang, M. D., Xu, P. P., Chen, W., Ni, Q. Q., Lu, G. M., \& Zhang, L. J. (2020). Coronavirus Disease 2019 (COVID-I9): A Perspective from China. Radiology, 200490. 


\section{APPENDIX -A}

\section{GE RIZAL LEARNING MODULE (Final Coverage) EDILMAR P. MASUHAY \\ Assistant Professor I SSCT -Mainit Campus}

\section{Introduction Statement:}

The Commission on Higher Education (CHED) released advisory relative to COVID-I9 of which the State universities and colleges (SUCs) has been mandated to undertake measures ensuring the safety of the students, faculty, staff and administration. Thus, Surigao State College of Technology (SSSCT) has responded and reciprocally demean traditional maneuvers hence attendance literally are not necessary, this is a resolution of vanishing the old methods of teaching, on the other hand modular concept has led to resolve the issue. This COVID-I9 definitely an uprising of a new beginning onward to educational teaching stratification but subsequently this is also threatening students of which their venue to attain the learning process is thru social media of which majority of the students avenues is going to public places where internet café is available where they are exposed, and prohibited for safety precautions (Signed by J. Prospero E. De Vera III, DPA).

However, in compliance to the institutional order, thereby modules are hereby formulated, below:

\section{MODULE I. CREATING REFLECTION ON JOSE RIZAL LIFE}

\begin{tabular}{ll}
\hline Learning Objectives & $\begin{array}{l}\text { Upon completion of this module, you will be able to: } \\
\text { Recognize Jose Rizal's contribution towards the country's development and } \\
\text { for this module } \\
\text { progress; } \\
\text { Acknowledge Jose Rizal's moral and intellectual legacies, philosophical and } \\
\text { religious ideas. }\end{array}$ \\
\hline Learning Activities & $\begin{array}{l}\text { Read previous studies on Jose Rizal's contribution towards the country's } \\
\text { development and progress; Related article, notes, magazine. } \\
\text { ftudents Learning Activities } \\
\text { Observe the environment, surroundings and their influences to National } \\
\text { development. }\end{array}$ \\
\hline
\end{tabular}

\begin{tabular}{ll}
\hline Learning Outcomes & \\
\hline Standards & $\begin{array}{l}\text { Create and Submit reflection; insights, overview relative to life and works of Jose } \\
\text { Rizal on how it impacted the community. }\end{array}$ \\
\hline
\end{tabular}

\begin{tabular}{lll}
\hline Learning Resources & \\
\hline Required Resources & $"$ & Jose Rizal books, magazine, notes, fact sheets. \\
& & Jose Rizal related blogs. \\
\hline Additional Resources & " & Assessment Rubrics \\
\hline
\end{tabular}

\section{ASSESSMENT RUBRICS}

\begin{tabular}{lccc}
\hline \multicolumn{1}{c}{ Items } & I & Score (Numerical Rating) & 2 \\
\hline Objective & $\begin{array}{c}\text { Shows worthy questions and } \\
\text { intention. }\end{array}$ & $\begin{array}{c}\text { Unclear questions and } \\
\text { unclear intention. }\end{array}$ & $\begin{array}{c}\text { Question and intention is } \\
\text { not match. }\end{array}$ \\
\hline Data Gathering & $\begin{array}{c}\text { Sufficient and accurate data } \\
\text { collected. }\end{array}$ & $\begin{array}{c}\text { Data is accurate, needs } \\
\text { improvement. }\end{array}$ & $\begin{array}{c}\text { Limited data, making } \\
\text { interpretation difficult. }\end{array}$ \\
\hline Analysis & $\begin{array}{c}\text { Logical conclusion connect } \\
\text { on the scientific principles } \\
\text { being studied. }\end{array}$ & $\begin{array}{c}\text { Data is connect the studies } \\
\text { but not accurate. }\end{array}$ & $\begin{array}{c}\text { Data does not lead to } \\
\text { conclusion. }\end{array}$ \\
\hline Presentation & $\begin{array}{c}\text { Science concepts are } \\
\text { expressed well and with full } \\
\text { citations support. }\end{array}$ & $\begin{array}{c}\text { Science concepts are } \\
\text { presented but non citations } \\
\text { support. }\end{array}$ & $\begin{array}{c}\text { Non science concept and } \\
\text { unorganized manner. }\end{array}$ \\
\hline References/Citations & Completed and properly & Complete citations and & Incomplete or poorly cited. \\
\hline
\end{tabular}




\section{MODULE 2. CREATING ARTICLE RELATIVE TO JOSE RIZAL LIFE, WORKS AND LITERATURES}

\begin{tabular}{|c|c|c|}
\hline \multicolumn{3}{|l|}{ Learning Objectives } \\
\hline $\begin{array}{l}\text { Student Learning Objectives } \\
\text { for this module }\end{array}$ & \multicolumn{2}{|c|}{$\begin{array}{l}\text { Upon completion of this module, you will be able to: } \\
\text { - Acknowledge the significance of Jose Rizal's Life, Works, Writings and his } \\
\text { execution. }\end{array}$} \\
\hline \multicolumn{3}{|l|}{ Learning Outcomes } \\
\hline Standards & \multicolumn{2}{|c|}{$\begin{array}{l}\text { - Create and submit descriptive historical research paper/article relative to the Life, } \\
\text { Works, Writings of Jose Rizal execution, and Religious ideas. }\end{array}$} \\
\hline \multicolumn{3}{|l|}{ ASSESSMENT RUBRICS } \\
\hline & \multicolumn{2}{|r|}{ Score (Numerical Rating) } \\
\hline Items & I & 2 \\
\hline Title & $\begin{array}{l}\text { Connected to Jose Rizal's } \\
\text { Patriotism, Nationalism and } \\
\text { Heroism }\end{array}$ & $\begin{array}{l}\text { Relative to Jose Rizal's Life } \\
\text { but not to Patriotism, } \\
\text { Nationalism and Heroism }\end{array}$ \\
\hline Abstract & $\begin{array}{l}\text { Accurately presented the } \\
\text { objective, problems, } \\
\text { significance, methods, } \\
\text { findings, conclusions. }\end{array}$ & $\begin{array}{c}\text { Presented the objective, } \\
\text { problems, significance, } \\
\text { methods, findings, } \\
\text { conclusions but not accurate. }\end{array}$ \\
\hline Introduction & $\begin{array}{l}\text { Shows the problems, data } \\
\text { gathering methods, and } \\
\text { purpose of the study. }\end{array}$ & $\begin{array}{l}\text { Uncertain problems, method } \\
\text { of gathering data, purpose of } \\
\text { the study. }\end{array}$ \\
\hline $\begin{array}{l}\text { Findings (Related Studies) } \\
\text { and Discussions }\end{array}$ & $\begin{array}{l}\text { Showcase scientific and } \\
\text { factual findings and } \\
\text { interpretation. }\end{array}$ & $\begin{array}{l}\text { Showcase findings and } \\
\text { interpretation but not } \\
\text { scientific and logical. }\end{array}$ \\
\hline Conclusions & $\begin{array}{l}\text { Completely answered the } \\
\text { questions and problems } \\
\text { stated on the introduction } \\
\text { subsection. }\end{array}$ & $\begin{array}{l}\text { Conclusion presentation } \\
\text { answers questions and } \\
\text { problems but need to be } \\
\text { enhance. }\end{array}$ \\
\hline References/Citations & $\begin{array}{l}\text { Completed and properly } \\
\text { cited. }\end{array}$ & $\begin{array}{c}\text { Complete citations and } \\
\text { references, Needs to be } \\
\text { enhance }\end{array}$ \\
\hline \multicolumn{3}{|l|}{ Learning Resources } \\
\hline Required Resources & \multicolumn{2}{|c|}{$\begin{array}{ll}\text { - } & \text { Jose Rizal books, magazine, notes, fact sheets. } \\
\text { - } & \text { Jose Rizal related blogs. } \\
\end{array}$} \\
\hline Additional Resources & - $\quad$ Assessment Rubrics & \\
\hline
\end{tabular}

\section{DepEd: Use of social media for learning still 'discouraged' despite COVID-I9 threat}

The Department of Education (DepEd) remains firm on its stand to highly discourage the use of social media platforms for learning while classes are suspended due to the coronavirus disease 2019 (COVID-19). "While social media are the easiest mediums to deliver information in this digital age using the latest on-hand technologies, the use of the platform also opens one's identity to the world wide web, making young learners exposed to different cyber threats," he said. Even though social media may be considered the "brightest innovation of this era," Pascua urged educators to "look at the bigger picture, where the reality is that social media in itself is not the proper medium for schools to use, especially in connection [with] the delivery of lessons especially since there are many options specifically designed for educational use." Given this, DepEd noted that there are existing open-source Learning Management Systems (LMS) that schools can use to support the e-learning requirements of an institution. DepEd also introduced the use of open educational resources (OER) to promote "equitable and quality education" to all 
Filipino learners. OERs refer to free and/or available educational materials that come with the permission for anyone to use, modify or share (Merlina Hernando-Malipot, 2020).

By facts, it is adherence to its reality that social media would possibly making young learners exposed to different cyber threats besides this actions may directly contradicting for the safety against the disease hence, its natural phenomena foretells that majority of the students could didn't have their own access and possibly their avenues is going to the public places where internet is available.

\section{UNICEF Philippines statement on COVID-I9}

MANILA, I3 March 2020 - Following President Rodrigo Duterte's declaration placing Metro Manila under lockdown from I5 March 2020 to I4 April 2020, UNICEF Philippines remains steadfast in working with the Philippine Government and partners to stop the transmission of the virus and to keep children and their families safe. UNICEF Philippines has been fully supporting the Government's emergency response as early as the first few cases of COVID-I9 were identified in the country. Just recently, we provided tents to the Department of Health $(\mathrm{DOH})$ to support the management of COVID-I9 cases requiring hospital care. $\mathrm{DOH}$ is further strengthening its capacity in hospital preparedness, rapid response, risk communication, and information dissemination with full support from UNICEF Philippines. UNICEF is working with DOH to take appropriate measures for the continuous delivery of other essential public health services including access to water, sanitation and hygiene, mental health and psychosocial support, and nutrition. "We are intent on staying on the ground working to mitigate impact on children and their families including pushing back against stigma associated with vulnerable groups," said Wigdan Madani, UNICEF's Chief of Health \& Nutrition, "and we remain concerned by related control measures including school closures, the burden on local health systems for the delivery of primary care, protection risks, and economic pressures felt by families.” With the suspension of classes in all levels within Metro Manila and in selected LGUs until I2 April 2020, UNICEF Philippines encourages schools to plan continuity for learning. We urge communities, caregivers, and parents to stay informed about COVID-I9 through trusted sources like the DOH, local government units, WHO, and UNICEF to recognize symptoms, coordinate with schools to support safety efforts, and help children cope with the stress caused by the current situation. Characterizing COVID-I9 as a pandemic is not an indication that the virus has become deadlier. Rather, it is an acknowledgement of the disease's geographical spread. Let's continue to prepare and respond to the epidemic to protect children and families in the Philippines (Gimeno, 2020).

This scenario has made the country panic, and even lockdown, controlling the economic activities some geographical places just to ensure the populace free from Covid-I9 infection, factual evidence demonstrated below:
f LGU-Mainit 2020 a
Li) Editmar

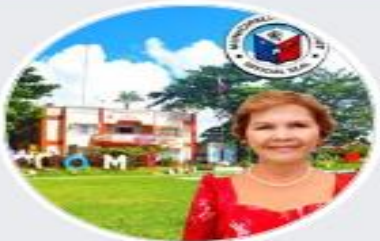
LGU-Mainit 2020 (C)Igumainitofficialpage Home Posts Videos Photos About Community Create a Page It Like $\mid$ I Follow $\Rightarrow$ Share $|\cdots|$
LGU-Mainit 2020 added 31 new photos to the album: MAINIT COMMUNITY QUARANTINE STATUS 03.18.2020 March 18 at 2:19 PM - 8
Upholding the Executive Order No. 33 series of 2020 issued by the Local Chief Executive (LCE) Honorable Crisanta O. Mondano, Ed.D dated March 16,2020 , the front line service provider such as the Barangay Council, Traffic Enforcers, Barangay Peacekeeping Action Team (BPAT) Barangay Health Workers (BHW), Barangay Health Emergency Response Team (BHERT) supported by the Philippine National Police (PNP) Mainit Police Station (MPS) Armed Forces of the Philippines (AFP) 30 Infant... See More

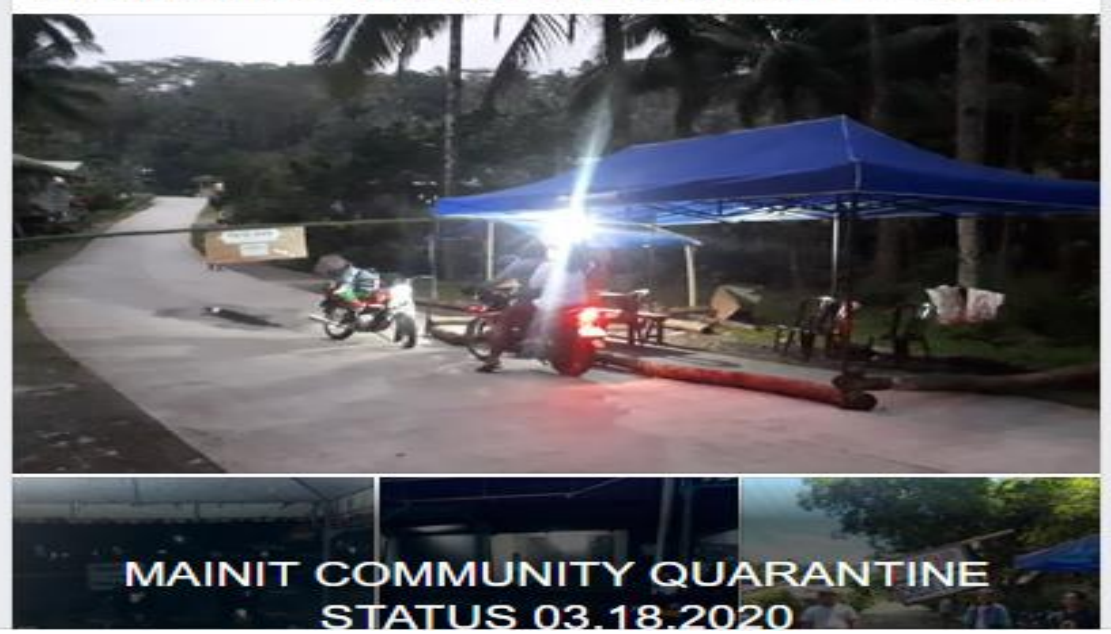




\section{CHED tells affected schools to move graduation dates amid COVID-I9 scare}

MANILA - The Commission on Higher Education on Saturday released a set of guidelines for social distancing and hygiene, as the Philippines braced for the spread of the coronavirus disease 2019 (COVID-I9). In an advisory issued Saturday, March I4, the CHED said educational institutions in Metro Manila, where a region-wide quarantine is now in effect, shall "abide by the directives of the Department of Health $(\mathrm{DOH})$ and the Department of Interior and Local Government (DILG) in the imposition of general and enhanced community quarantine in their respective jurisdictions." One directive is the suspension of classes on all levels. Metro Manila schools using the old academic calendar, or schools ending their academic years in March or April, are required to move or cancel their graduation ceremonies, citing the restriction on mass gatherings mandated by the Inter-agency Task Force on Emerging Infectious Diseases. Schools, which have shifted their academic calendar to June or July, do not need to postpone graduation ceremonies. However, their semesters "may need to adjust as needed" to compensate for the month-long class suspensions. Employees of educational institutions are also advised to practice social distancing. Students who can't go to school for 30 days due to the quarantine should not be evicted from class, the CHED added. Local government units could suspend classes as long as "measures and arrangements are in place to allow the students to continue fulfilling their requirements." The CHED also urged schools outside Metro Manila to develop contingency plans, sanitize their facilities, and discourage mass gatherings. It also suggested that plans to go to overseas internship programs, along with participation in contests outside, should be suspended. It likewise urged school administrators to practice "preventive measures such as proper hand hygiene, cough etiquette, and social distancing" (News, n.d.).

This situation is merely applicable to all SUCs not only in Metro Manila, see order of suspensions in Diliman University Philippines and City mayor ordinance, for exhibited purposes, below:

- Classes, both residential and online and alternative learning activities in the UP System (except the UP Open University) are suspended until I4 April 2020 while the University assesses the situation and decides on how best to facilitate learning and manage academic requirements in the time of COVID-I9 (UP Diliman - University of the Philippines, n.d.);

- BACOLOD CITY - Mayor Evelio Leonardia has issued an executive order (EO) suspending the graduation and moving-up ceremonies in all levels of public and private schools here until further notice due to the threat of the coronavirus disease 2019 (Covid-19).

\section{CHED urges schools to prepare for possible coronavirus 'community-level transmission'}

MANILA, Philippines - The Commission on Higher Education (CHED) called on state universities and colleges to prepare for possible community-level transmission of COVID-19, the disease caused by the novel coronavirus. In a memorandum order released on Wednesday, March I0, CHED chairman Prospero de Vera III reiterated that schools should have protocols in place to stop the spread of the novel coronavirus within the campus in coordination with the Department of Health. These include creating screening procedures for symptomatic students, faculty, staff and administrators; preparing health clinics to accommodate and isolate patients potentially infected with the novel coronavirus; and performing decontamination and disinfection of buildings in schools. (READ: DepEd says proceeding with graduation ceremony 'up to school's discretion'). President Rodrigo Duterte suspended classes in all levels in Metro Manila from March IO to I4 following the spike of confirmed cases in the Philippines. Schools are advised to coordinate with their affiliated training establishments for any adjustment on training hours; and consider alternative modes for on-the-job training, practicum and internships. (READ: How Metro schools continue lessons amid coronavirus threat). But based on the assessment in their areas, all schools should be flexible in adjusting the academic calendar, foregoing other curricular activities for the semester and exercising discretion to possibly postpone graduation ceremonies (CHED urges schools to prepare for possible coronavirus 'community-level transmission, 'n.d.).

This argumentation has been confusing for teacher, students and even by the policy-makers hence crafted statement below were simplified that this Covid-I9 had impacted either ruined the judgment of our educators and the learners: 


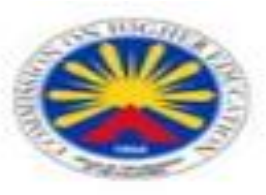

Statement

\begin{abstract}
I have received complaints from students who are unable to comply with requirements of universities/colleges (examinations, reports, and assignments) using online/distance learning mode because of poor internet connection and the policy of home quarantine. HEls must exercise leniency and help the students during these difficult times. CHED is monitoring the situation and will take the necessary corrective actions if HEls do not act accordingly.
\end{abstract}

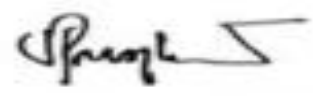

\title{
J. PROSPERO E. DE VERA III, DPA \\ Chairman
}

Commission on Higher Education

This letter or statement has clearly stated that students has been complaining about social media activities as part of the learning process and the CHED were advising that students adversaries should be given consideration, submissively the SUCs President of SSCT has progressively ordered that all faculty should prepared a module, this by then expected that initiative will be within the scope of the teacher to maneuver the learning process as well. However, this concepts has been thoroughly demean by some instances, see some students' social media-communication bellows:
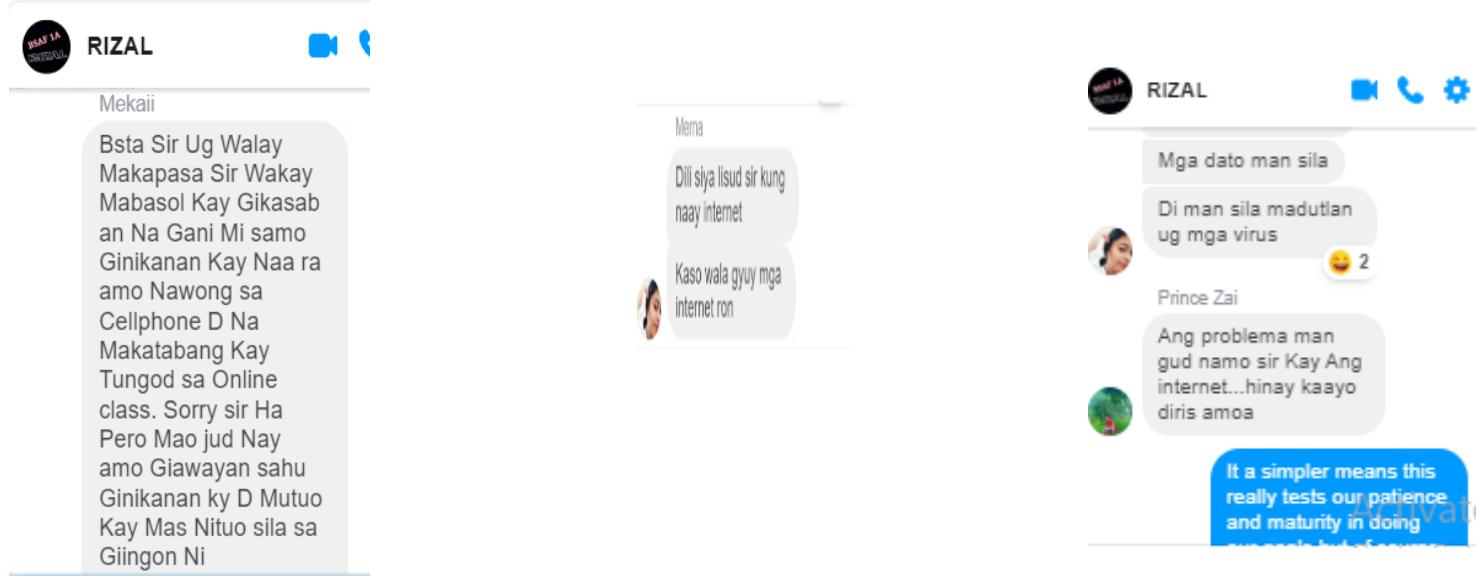

Students' were explaining their side to be understood that this phenomenal crisis has put them on the line of distress, their parents were already complaining and there is no internet access for them to comply the requirements and to follow the learning process.

\section{Copyrights}

Copyright for this article is retained by the author(s), with first publication rights granted to the journal. This is an open-access article distributed under the terms and conditions of the Creative Commons Attribution license (http://creativecommons.org/licenses/by/4.0/). 